\title{
The Supply of Science Teachers to Secondary Schools in Ondo State, Nigeria: A Critical Analysis
}

\author{
Adeyemi, T. O. ${ }^{9}$
}

\section{Abstract}

This paper investigated the supply of science teachers to secondary schools in Ondo State, Nigeria. It was an ex-post facto and descriptive research. The study population comprised all the 281 secondary schools and 4 higher institutions in the State as well as 30 higher institutions from neighbouring States producing teachers for secondary schools. The sample in respect of secondary schools was identical with the population. Since only 2 out of the 4 higher institutions in the State produce teachers, the 2 higher institutions were selected for the study. Out of the 30 higher institutions in neighbouring States, 16 were selected thereby giving a total sample of 18 higher institutions. The method of selection was by multi-stage, purposeful and stratified random sampling. The instrument used was an inventory while the data collected were analyzed using frequency counts and percentages. It was found that science teachers were in less proportion compared to non-science teachers in all the schools. Male science teachers were in greater numbers than female science teachers in the schools. The number of science teachers supplied from higher institutions outside the State was greater than the number supplied from higher institutions within the State The supply of science teachers did not match the demand for them in the schools. It was concluded that higher institutions in the State had not been supplying sufficient number of science teachers to the schools. It was then recommended that more efforts should be made by government to increase the supply of science teachers to schools.

Keywords supply of science teachers, demand for science teachers, enrolment growth rates

\section{Introduction}

The origin of secondary education in Ondo state, Nigeria dated back to 1919 when the first secondary school was established by the Christian Missionaries. By 1960, when Nigerian attained independence, the number had increased to 39. Since independence, the demand for secondary education increased tremendously such that by 1979 when the free secondary education was launched, the number had increased to 251. The free education policy of government further led to a considerable expansion in the number of secondary schools. The number thereby rose to 501 in 1983 while students' enrolment increased from 149,037 to 304,452 during the period (Ondo State Ministry of Education, 1985). However, as a result of the economic crunch in the country, the number of secondary schools in the State was reduced to 463 in 1986 and to 281 in 1996 (Ondo State Ministry of Education, 2006).

However, noting the State government's intention to orientate school programmes in the State towards science and technology, one major concern to educationists. (Ige, 2001; Olugbile, 2007)

${ }^{9}$ Dr. T. O. Adeyemi lecturers at the Department of Educational Foundations and Management, University of AdoEkiti, P. M. B 5363, Ado-Ekiti, Nigeria. E-mail: toade1957@yahoo.com 
was the problem of getting an increased supply of qualified science teachers for the schools. The problem was compounded by the expansion in the number of secondary schools in the State. However, the intention of government to train more qualified science teachers was always hampered by financial constraints, which was perhaps the result of the weak economic base of the State. In a healthy economy, certain conditions must be met. These conditions include rational investment in programmes of immediate and long-term promise and benefits; reduction of governments' commitments to 'consumer' oriented programmes and limiting government's dependence on outside sources of income. Others include constant checking on levels of recurrent expenditure, encouraging private contribution to governments' programmes and formulating a radical programme for internally generated funds (Adesina, 1982).

Contrary to the fairly strong level of the national economy, the Ondo State economy has been on a low level since its creation. Agriculture was therefore the mainstay of the State's economy accounting for 75 per cent of the adult population and 70 per cent of the Gross Domestic Product (Ondo State Government, 2000). Since, the State could only generate less than 10 per cent of its financial commitment (Ondo State Government, 2001), it had to rely on statutory allocations from the Federal Government, grants and loans from various sources.

\section{Literature Review}

Supply, an economic concept had been described as the quantity of a commodity that is called into the market over a particular period of time at specific prices (Nwankwo, 1981; Bradley, 1999).. An increase in supply tends to lower the price and increase the quantity demanded. Conversely, a decrease in supply causes a rise in price and consequently reduction in the quantity demanded. Relating the supply situation to education, prices such as salaries (the price of labour) are determined in the same way as the prices of goods. The major determinants of the supply of science and non-science teachers are the salaries or wages. Teachers' salaries are good determinants when considering the economics of supply of teachers. This is because the educational system competes with other occupation in the labour market in a market economy. In view of the fact that the period of training of teachers takes considerable long time, it becomes difficult, for market forces to provide immediate solution to the supply of teachers (Akangbou, 1985, Nwadiani, 1996). Notwithstanding, as far as the supply of qualified teachers is concerned, the salary to be paid each teacher represents the price at which the offer of appointment is made; and these salaries are crucial in determining the extent of supply of qualified teachers. Enrolment is another determinant of the supply of qualified teachers. This is in view of the fact that an increase or decrease in enrolment determines the number of qualified teachers to be recruited. Hence, researchers have suggested the need for the mass production of Bechelors of Education graduates for secondary schools (Darling-Hammond \& Sclan, 1996; Aghenta, 1998).

Demand, another basic concept in Economics had been described by Nwankwo (1981) as the quantity of goods required at given prices during a certain period. The higher the price of the community, the less the quantity of it that can be bought and the less the demand. An increase in demand, on the other land, causes a rise in price and a rise in the quantity to the market. Thus, there is a linkage between the price of a commodity and the quantity required of that commodity. Demand in education bears little relationship to the usual economic meaning of demand for goods at various prices (Bradley, 1999). The major determinant of the demand for qualified teachers is enrolment. Hence, an increase in students' enrolment causes a rise in the demand for qualified teachers. Other determinants of the demand for teachers include: the teacher-student 
ratio, the range of subjects taught, number of classes in the schools, minimum class size, number of periods per teacher per week, teaching methods and the size distribution of schools (Sheehan, 1973, Yasin, 1999). As such, the number of teachers required in a school depends largely on students' enrollment growth patterns, the pace of teacher retirement and attrition, and desired teacher-student ratios. Other factors, such as high immigration rates within the population or policies on reducing class size, also contribute to the demand for new teachers (Yasin, 1998).

The manpower requirement approach has great relevance to the demand for qualified teachers in schools. This approach is based on the fact that any nation with plans or aspirations for economic development must consider the preparations of its human aspects of development. (Musaazi, 1982). This idea supported Nwankwo's (1981) contention that modern production has demand for precise skills and the number of people with those relevant skills. In making this estimation, it was assumed that if the national economy was to achieve 4 per cent of economy growth, the senior and intermediate manpower should grow at the rate of 8 and 13 per cent respectively (Ashby Report, 1961; Adesua, 1981; Onifade, 2003).

Considering the importance attached to education as revealed from government finances to the education sector and the emphasis given in the National Policy on Education (Federal Government of Nigeria, 2004) on the orientation of the country towards technological development, one is tempted to believe that there was an adequate supply of science teachers to secondary schools in the State. Although qualified teachers are available in varying proportions in both science and non-science subjects of the schools' curriculum, the expansion in the number of secondary schools in Ondo State, Nigeria has led the researcher to investigate the supply of science teachers to the schools in the State in order to correct any erroneous impression.

\section{Statement of the Problem}

The proliferation of secondary schools in all parts of Ondo State, Nigeria as a result of the free education policy of government and the attendant increase in the students' enrolment have brought about the demand for more qualified science teachers in many of the schools (Adeyemi, 1998; Ige, 2001). Although the State government took various measures to supply more science teachers to schools, it seems that there is perhaps a mis-match in the supply and demand of science teachers in the schools...

Although qualified teachers were needed in the science and non-sciences subjects, the demand for qualified teachers appears to be more pronounced in science subjects than in non-sciences subjects. Considering the rapid expansion in the number of secondary schools in the State, the issue of whether or not adequate number of qualified science teachers has been supplied to secondary schools in the State constituted the problem of this study.

\section{Research Questions}

In addressing the problem of this study, the following research questions were raised:

1. What is the staffing position of science teachers compared to non-science teachers in secondary schools in Ondo State, Nigeria?

2. What are the enrolment growth rates for science students and teacher-student- ratio in science subjects in secondary schools in the State? 
3. How does the supply of qualified science teachers from higher institutions within the State compare with the supply of science teachers from higher institutions from neighbouring States?

4. How does the supply of qualified science teachers compare with the supply of nonscience teachers to secondary schools in the State?

5. Does the supply of qualified science teachers match the demand for them in secondary schools in Ondo State, Nigeria?

6. What is the projection of supply of and demand for science teachers to secondary schools in the State for the period 2007 to 2016 ?

\section{Method}

This study was an ex-post facto and descriptive survey. Gay (1996) described an ex-post facto research as an after fact or after event research while Babbie (1973) described a survey is a study being conducted for the purpose of making descriptive assertions about some populations.

The study population comprised all the 281 secondary schools and 4 higher institutions in the State as well as 30 higher institutions from neighbouring States producing teachers for secondary schools. The sample in respect of the number of secondary schools was identical with the population (Moore, 1994) as all the schools were involved in the study. Since teachers are supplied into the State secondary schools from higher institutions in Nigeria and overseas, the supply of teachers was delimited to higher institutions within Ondo State and higher institutions in 9 neighbouring States namely Ekiti, Osun, Oyo, Ogun, Kwara, Kogi, Edo, Delta and Lagos States having Ondo State as a catchment area in the admission of students. Since only 2 out of the 4 higher institutions in the State produce teachers for secondary schools, the 2 higher institutions were selected for the study. Out of the 30 higher institutions in neighbouring States, 16 were selected thereby giving a total sample of 18 higher institutions. The method of selection was by multi-stage, purposeful and stratified random sampling techniques. The principals of the secondary schools and the Heads of Departments of the Faculties of education in the higher institutions were the respondents.

Two inventories were used for the study. These were the secondary schools principals' inventory and the higher institutions teacher supply inventory. The secondary schools principals' inventory sought information on students' enrolment in the schools, number of classes, staffing situation with regard to the total number of qualified teachers demanded and the total number of teachers in place. The higher institutions teacher supply inventory requested for information on the number of Ondo State students produced by the institutions between 2002 and 2006. The content validity of the instrument was determined by experts in educational planning who matched each item of the inventories with the research questions in order to ascertain whether the instruments adequately measured the content area of the study.. Their remarks were used as a guide in reviewing the instruments before they were administered. The completed copies of the instruments were retrieved from the respondents after a period of two weeks. The data collected were analyzed using descriptive statistics such as frequency counts and percentages. 


\section{Analysis and results}

Question $1 \quad$ What is the staffing position of science teachers compared to non-science teachers in secondary schools in Ondo State, Nigeria?

In answering this question, data on the distribution of teachers on the basis of science and nonscience subjects were collected from the respondents using the inventory. The data were analyzed with the use of percentages. The findings showing the ratio of all science teachers to non-science teachers in all the schools are presented in Table 1.

Table 1 Staffing Position of Science and Non- Science Teachers to Secondary Schools in Ondo State, Nigeria

\begin{tabular}{llllllllll}
\hline & & \multicolumn{3}{c}{ Number of Science Teachers } & \multicolumn{3}{c}{ Number of Non- Science Teachers } \\
Years & Total at post & Male & Female & Total & $\%$ & Male & Female & Total & $\%$ \\
\hline 2002 & 9366 & 1525 & 1285 & 2810 & 30.0 & 3056 & 3500 & 6556 & 70.0 \\
2003 & 9542 & 1636 & 1308 & 2944 & 30.9 & 2856 & 3742 & 6598 & 69.1 \\
2004 & 9735 & 1840 & 1372 & 3212 & 33.0 & 2767 & 3756 & 6523 & 67.0 \\
2005 & 9933 & 1974 & 1535 & 3509 & 35.3 & 2654 & 3770 & 6424 & 64.7 \\
2006 & 10,185 & 2060 & 1610 & 3670 & 36.0 & 2693 & 3822 & 6515 & 64.0 \\
Average & Total & & & & $33 \%$ & & & & $67 \%$ \\
\hline
\end{tabular}

Table 1 shows that science teachers were in few numbers in secondary schools in Ondo State, Nigeria. They constituted only $30 \%$ of the total number of teachers in the schools in year 2002, $30.9 \%$ in $2003,33.0 \%$ in $2004,35.3 \%$ in 2995 and $36 \%$ in 2006 . On the average, they constituted only $33 \%$ of the total number of teachers in the schools in the State. Conversely, the non-science teachers formed the bulk of teachers. They constituted $70 \%$ of all the teachers in the schools in year 2002, 69.1\% in 2003, 67\% in 2004, 64.7\% in 2005 and 64.0\% in 2006. On the average, non-science teachers constituted $67 \%$ of all teachers in the schools. It could be deduced from the findings that science teachers were in a small proportion when compared with the number of non-science teachers in all schools in the State. Further analysis shows that male science teachers were in greater numbers than female science teachers. Conversely female nonscience teachers were in greater numbers than male non-science teachers. The distribution of the teachers by qualification is shown in Table 1.

Table 2 Number of Science and Non- Science Teachers by Qualification in Secondary Schools in Ondo State, Nigeria

\begin{tabular}{|c|c|c|c|c|c|c|c|c|c|}
\hline \multirow[b]{3}{*}{ Years } & \multirow{3}{*}{$\begin{array}{l}\text { Total at } \\
\text { post }\end{array}$} & \multicolumn{4}{|c|}{ Science Teachers } & \multicolumn{4}{|c|}{ Non- Science Teachers } \\
\hline & & \multicolumn{2}{|c|}{$\begin{array}{c}\text { Qualified with } \\
\text { (MEd, BEd } \\
\text { BSc/BA Ed, } \\
\text { BSc/BA+PGDE; } \\
\text { NCE) }\end{array}$} & \multicolumn{2}{|c|}{ Unqualified } & \multicolumn{2}{|c|}{$\begin{array}{l}\text { Qualified with } \\
\text { (MEd, BEd } \\
\text { BSc/BA Ed, } \\
\text { BSc/BA+PGDE; } \\
\text { NCE) }\end{array}$} & \multicolumn{2}{|c|}{ Unqualified } \\
\hline & & Number & $\%$ & Number & $\%$ & Number & $\%$ & Number & $\%$ \\
\hline 2002 & 9366 & 2705 & 28.9 & 105 & 1.1 & 6346 & 67.8 & 210 & 2.2 \\
\hline 2003 & 9542 & 2830 & 29.7 & 114 & 1.2 & 6382 & 66.9 & 216 & 2.2 \\
\hline 2004 & 9735 & 3094 & 31.8 & 118 & 1.2 & 6303 & 64.7 & 220 & 2.3 \\
\hline 2005 & 9933 & 3387 & 34.1 & 122 & 1.2 & 6200 & 62.4 & 224 & 2.3 \\
\hline 2006 & 10,185 & 3540 & 34.8 & 130 & 1.3 & 6287 & 61.7 & 228 & 2.2 \\
\hline
\end{tabular}


The Supply of Science Teachers to Secondary Schools in Ondo State, Nigeria: A Critical Analysis Adeyemi, T. 0.

In Table 2, the proportion of science teachers in the schools was still lower than non-science teachers. Although unqualified teachers were few in science and non-science subjects, qualified science teachers were in a lower proportion than qualified non-science teachers through the period of study. In 2002 for instance, qualified science teachers accounted for only $28.9 \%$ of the total number of teachers in the schools while in year 2003, they accounted for only $29.7 \%$. In year 2004, they accounted for 31.85 while in years 2006 and 2006, they accounted for 34.1\% ands $34.8 \%$ respectively. Figure 1.1 depicts the staffing position in the schools.

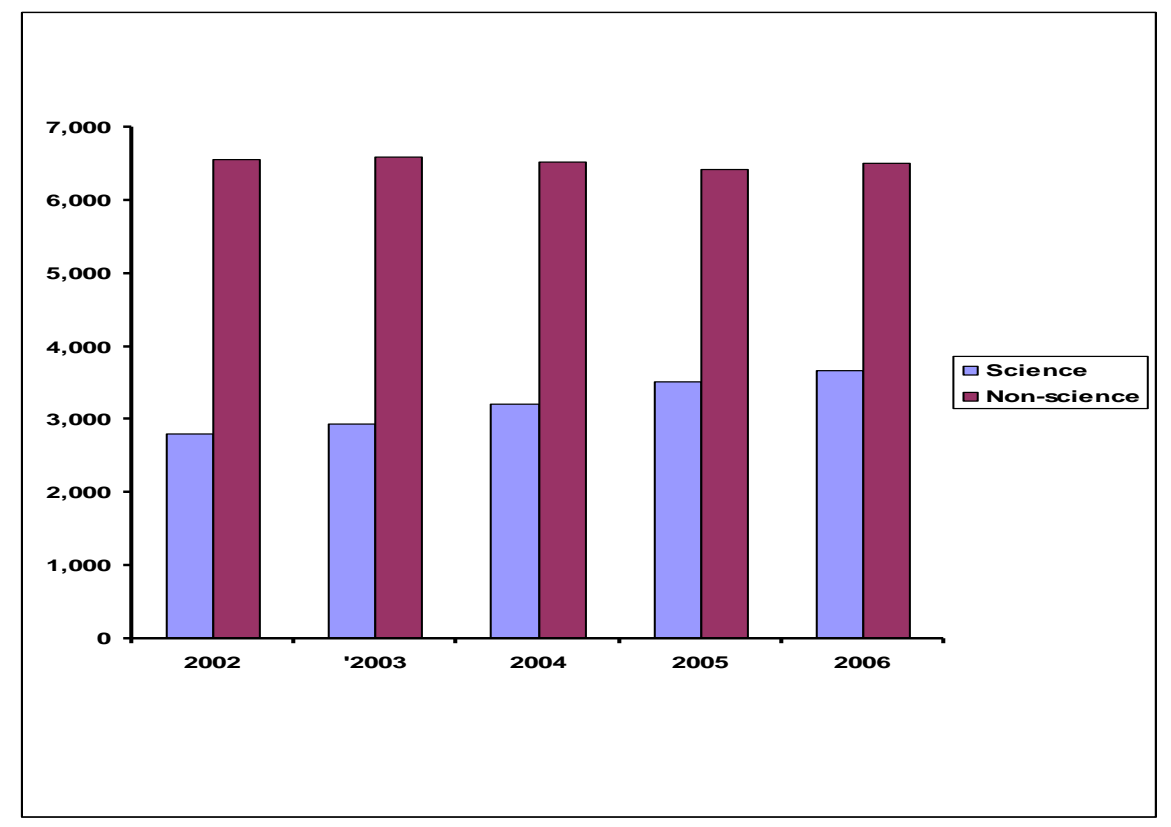

Figure 1

Staffing Position of Science and Non- Science Teachers to Secondary Schools in Ondo State, Nigeria

As shown in Figure 1, the ratio of science teachers was lower than for non-science teachers. This finding was a negation to the provision of the Nigerian National Policy on Education which recommended a ratio of 40:60 science to non-science teachers in all secondary schools in the country (Federal Government of Nigeria, 2004).

Question 2 What are the enrolment growth rates for science students and teacher-studentratio in science subjects in secondary schools in the State?

In response to this question, data on the number of students offering science subjects in secondary schools in the State were collected from the principals of the schools through the inventory for five years 2002 to 2006. The data collected were collated and analyzed using frequency counts and percentages. The computing the enrolment growth rate for science students in the schools was based on the increase in students' enrolment for one year divided by the previous year's enrolment using the following formula (Adesina, 1982):

$$
\begin{aligned}
\mathbf{E}_{\mathbf{n}}= & \frac{\mathbf{E}_{\mathbf{t}}-\mathbf{E}_{\mathbf{t}-\mathbf{1}}}{\mathbf{E}_{\mathbf{t}-\mathbf{1}}} \times \mathbf{1 0 0} \\
\text { Where } & \mathrm{E}_{\mathbf{n}} \text { Enrolment growth; } \\
& \mathrm{E}_{\mathbf{t}}=\text { Enrolment in year } \mathrm{t} \text { (present year); } \\
& \mathrm{E}_{\mathbf{t}-\mathbf{1}}=\text { Enrolment in year } \mathrm{t}-1 \text { (previous year). }
\end{aligned}
$$


The findings are presented in Table 3. As indicated in Table 3, the enrolment growth rate among science students in the schools varied from one year to another. In year 2003, the enrolment growth rate was $0.03 \%$ while in year 2004, there was a sharp increase in student's enrolment in science subjects. Hence, the enrolment growth rate was $10.96 \%$. In year 2005 , there was a decline in the number of students offering science subjects in the schools. As such, the enrolment growth rate was $3.51 \%$. In year 2006, there was a further decline in the number of students offering science subjects in the schools. Hence, the enrolment growth rate was $2.12 \%$. On the whole, the average enrolment growth rate for science students in the schools was $4.2 \%$.

Table 3 Enrolment Growth Rate of science students in Secondary Schools in Ondo State, Nigeria

\begin{tabular}{lll}
\hline Years & $\begin{array}{l}\text { Total number of science } \\
\text { students enrolled }\end{array}$ & Growth Rate in \% \\
\hline 2002 & 55,601 & - \\
2003 & 55,618 & 0.03 \\
2004 & 61,716 & 10.96 \\
2005 & 63,885 & 3.51 \\
2006 & 65,242 & 2.12 \\
Average Growth Rate & $=$ & $4.2 \%$ \\
\hline
\end{tabular}

In determining the teacher-ratio among science teachers and students offering science subjects in the schools, data on the total number of students offering science subjects in senior secondary classes one to three (SS1 to SS30 were collected through the inventory. The number of science teachers teaching these students was also collected through the inventory. The teacher-student ratio was computed by dividing the total number of students in the schools by the number of teachers using the following formula (Adeyemi, 1998):

$$
\mathrm{T}_{\mathrm{s}}=\frac{\mathrm{N}_{\mathrm{s}}}{\mathrm{N}_{\mathrm{t}}}
$$

Where $T_{s}=$ Teacher-student Ratio; $N_{s}=$ Total number of students; $T_{t}=$ Total number of teachers.

On the basis of this formula, the teacher-student ratio in science subjects in secondary schools in the State between years 2002 and 2006 are shown in Table 4. In this table, the teacher -student ratio among students offering science subjects and science teachers varied from one year to another ranging between 1:18 to 1:19. The average teacher-student in the schools was however found to 1:18. Although the ratio is low, it should be noted that the figures contained both qualified and unqualified teachers in the schools. 
The Supply of Science Teachers to Secondary Schools in Ondo State, Nigeria: A Critical Analysis Adeyemi, T. 0.

Table 4 Teacher -student ratio in science subjects in secondary schools in Ondo State, Nigeria

\begin{tabular}{|lllll|}
\hline Years & $\begin{array}{l}\text { Total number of students } \\
\text { enrolled in the schools }\end{array}$ & $\begin{array}{l}\text { Total number of science } \\
\text { students enrolled }\end{array}$ & $\begin{array}{l}\text { Number of science } \\
\text { teachers in post }\end{array}$ & $\begin{array}{l}\text { Teacher- } \\
\text { student Ratio }\end{array}$ \\
\hline 2002 & 193,069 & 55,601 & 2926 & 19 \\
2003 & 198,634 & 55,618 & 2944 & 19 \\
2004 & 205,720 & 61,716 & 3212 & 19 \\
2005 & 212,949 & 63,885 & 3509 & 18 \\
2006 & 214,048 & 65,242 & 3670 & 18 \\
& & Average Teacher--Student Ratio $=1: 18$ & \\
\hline
\end{tabular}

Question 3 How does the supply of qualified science teachers from higher institutions within the State compare with the supply of science teachers from higher institutions from neighbouring States?

In answering this question, data was obtained from two sources. The first source embraced data on the number of qualified science teachers supplied into the teaching profession from higher institutions within the State while the second source embraced the number supplied from higher institutions in neighbouring States having Ondo State as a catchment area in the admission of students. The data were collected from the Heads of Departments of the various departments of the Faculties of Education in the higher institutions. The data collected were collated and analyzed using percentages. The findings are presented in Table 5.

Table 5: Number of qualified science teachers supplied to secondary schools in Ondo State

\begin{tabular}{|c|c|c|c|c|c|c|c|}
\hline Years & $\mathrm{N}$ & $\begin{array}{l}\text { Total } \\
\text { number of } \\
\text { qualified } \\
\text { teachers } \\
\text { supplied }\end{array}$ & $\begin{array}{l}\text { Number of } \\
\text { qualified } \\
\text { science } \\
\text { teachers } \\
\text { supplied }\end{array}$ & $\begin{array}{l}\text { Number of } \\
\text { qualified science } \\
\text { teachers supplied } \\
\text { by higher } \\
\text { institutions within } \\
\text { the State }\end{array}$ & $\%$ & $\begin{array}{l}\text { Number of } \\
\text { qualified science } \\
\text { teachers supplied } \\
\text { from higher } \\
\text { institutions in } \\
\text { neighbouring } \\
\text { States }\end{array}$ & $\%$ \\
\hline 2002 & 16 & 9856 & 3152 & 1420 & 45.1 & 1732 & 54.9 \\
\hline 2003 & 16 & 10,442 & 3550 & 1523 & 42.9 & 2027 & 57.1 \\
\hline 2004 & 16 & 11,893 & 3806 & 1736 & 45.6 & 2070 & 54.4 \\
\hline 2005 & 16 & 12,745 & 4210 & 2041 & 48.5 & 2169 & 51.5 \\
\hline 2006 & 16 & 14,651 & 5134 & 2474 & 48.2 & 2660 & 51.8 \\
\hline
\end{tabular}

Figure 2 shows the supply of qualified science teachers from higher institutions within the State and from higher institutions from neighbouring States, 


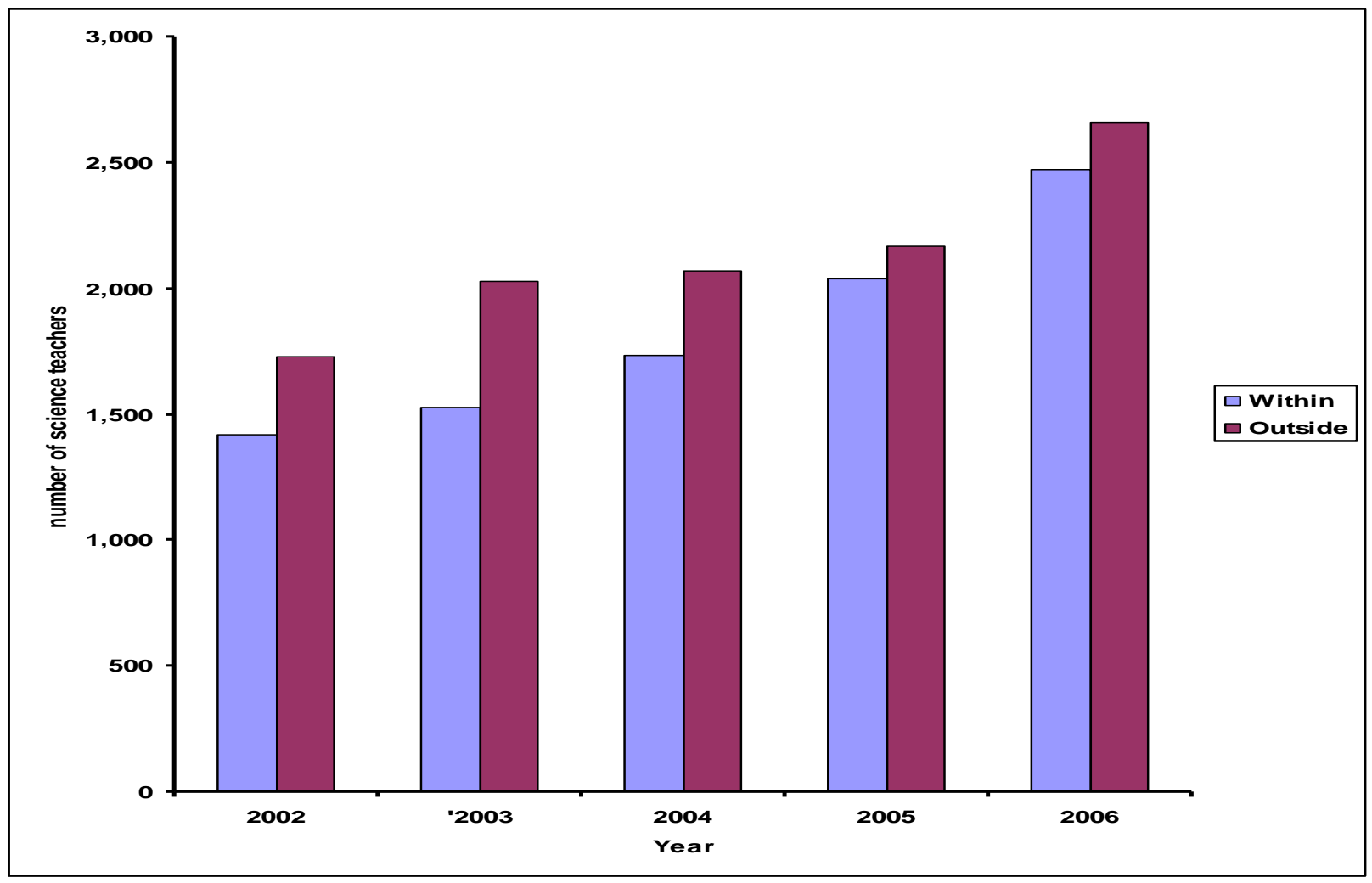

Figure 2 Supply of qualified science teachers from higher institutions within the State and from higher institutions from neighbouring States

As indicated in Table 5 and Figure 2, the number of science teachers supplied from higher institutions in neighbouring States was greater than the number supplied from higher institutions within the State in each of the years of study. The findings revealed that out of the 3152 science teachers supplied from the higher institutions in year 2002, only 1420 science teachers (45.1\%) were supplied from higher institutions within the State while 1732 science teachers $(54.9 \%)$ were supplied from higher institutions in neighbouring States having Ondo State as a catchment area in the admission of students. In year 2006, out of the 5134 qualified science teachers supplied from the higher institutions, 2474 science teachers $(48.2 \%)$ were supplied from higher institutions within the State while 2660 science teachers $(51.8 \%)$ were supplied from higher institutions in neighbouring States having Ondo State as a catchment area in the admission of students. This shows that the bulk of the science teachers supplied into secondary schools in the State were supplied from higher institutions in neighbouring States.

\section{Question $4 \quad H o w$ does the supply of qualified science teachers compare with the supply of non-science teachers to secondary schools in the State?}

In response to this question, data on the number of qualifies teachers supplied into secondary schools in Ondo State, Nigeria were collected from the heads of departments of the Higher Institutions within the State and higher institutions from neighbouring States through the inventory, the data were analyzed using percentages. The findings are shown in Table 6. 
The Supply of Science Teachers to Secondary Schools in Ondo State, Nigeria: A Critical Analysis Adeyemi, T. 0.

Table 6 Number of qualified science and non-science teachers supplied to secondary schools in Ondo State, Nigeria from sources within the State

\begin{tabular}{|c|c|c|c|c|c|c|c|c|}
\hline Years & $\mathrm{N}$ & $\begin{array}{l}\text { T otal } \\
\text { number of } \\
\text { qualified } \\
\text { teachers } \\
\text { supplied }\end{array}$ & $\begin{array}{l}\text { Number } \\
\text { of } \\
\text { qualified } \\
\text { science } \\
\text { teachers } \\
\text { supplied }\end{array}$ & $\begin{array}{l}\text { Number of } \\
\text { qualified } \\
\text { science } \\
\text { teachers } \\
\text { supplied from } \\
\text { higher } \\
\text { institutions } \\
\text { within the } \\
\text { State }\end{array}$ & $\%$ & $\begin{array}{l}\text { Number } \\
\text { of } \\
\text { qualified } \\
\text { non- } \\
\text { science } \\
\text { teachers } \\
\text { supplied }\end{array}$ & $\begin{array}{l}\text { Number of } \\
\text { qualified } \\
\text { non-science } \\
\text { teachers } \\
\text { supplied } \\
\text { from higher } \\
\text { institutions } \\
\text { within the } \\
\text { State }\end{array}$ & $\%$ \\
\hline 2002 & 16 & 9856 & 3152 & 1420 & 45.1 & 6704 & 3515 & 52.4 \\
\hline 2003 & 16 & 10,442 & 3550 & 1523 & 42.9 & 6892 & 3674 & 53.3 \\
\hline 2004 & 16 & 11,893 & 3806 & 1736 & 45.6 & 8087 & 4236 & 52.4 \\
\hline 2005 & 16 & 12,745 & 4210 & 2041 & 48.5 & 8535 & 4580 & 53.7 \\
\hline 2006 & 16 & 14,651 & 5134 & 2474 & 48.2 & 9517 & 5021 & 52.8 \\
\hline
\end{tabular}

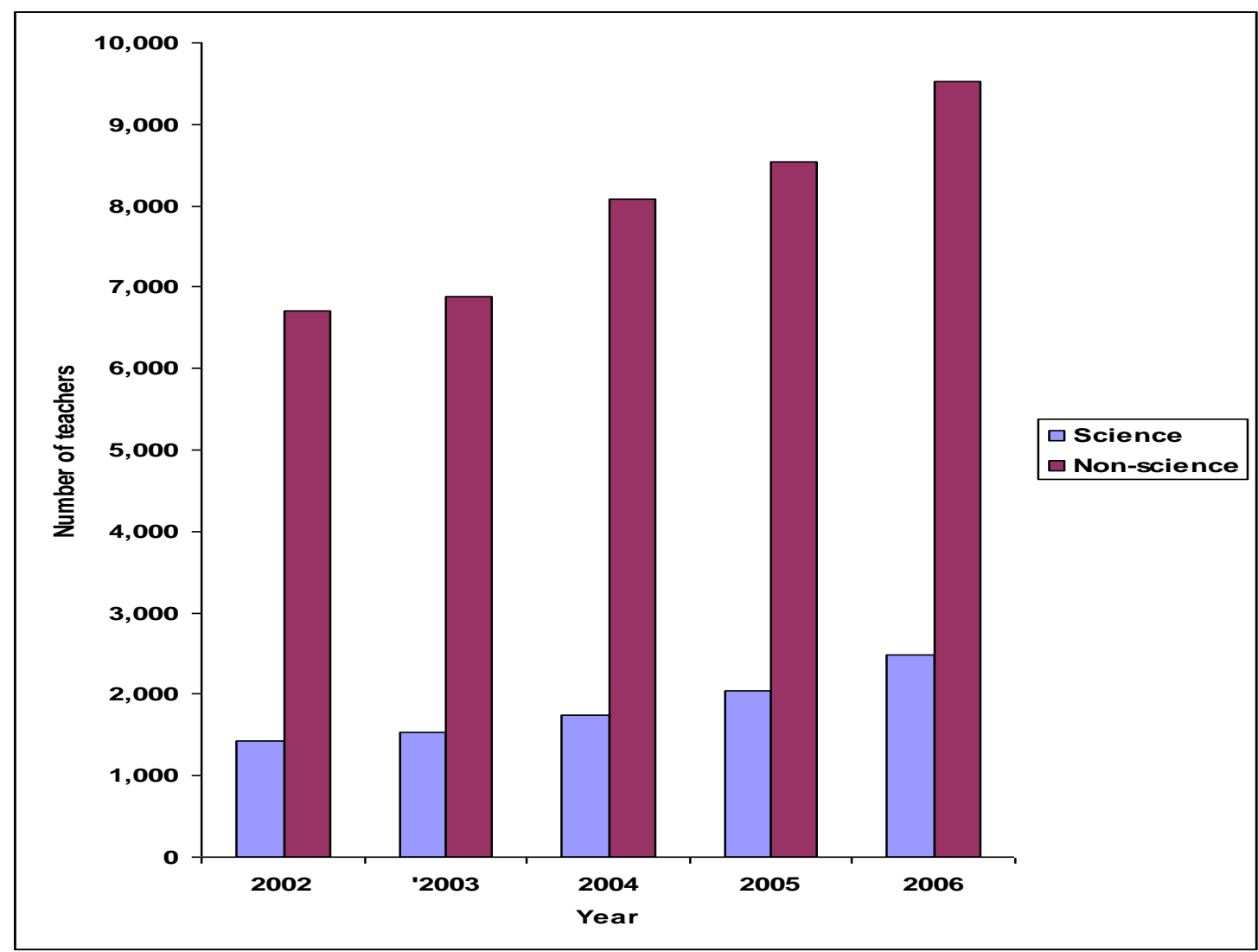

Figure 3

Graph showing the supply of qualified science and non-science teachers from higher Institutions within the State 
In Table 6 it was found that a greater number of qualified non-science teachers were supplied from institutions within the State than qualified science teachers. In year 2002, for instance, out of the 3152 qualified science teachers supplied, 1420 qualified science teachers $(45.1 \%)$ were supplied from higher institutions within the State whereas out of the 6704 qualified non-science teachers supplied, 3515 qualified non-science teachers (52.4\%) were supplied from higher institutions within the State. In year 2006, out of the 5134 qualified science teachers supplied, 2474 qualified science teachers $(48.2 \%)$ were supplied from higher institutions within the State whereas out of the 9517 qualified non-science teachers supplied, 5021 qualified non-science teachers $(52.8 \%)$ were supplied from higher institutions within the State. On the basis of comparison, Table 7 shows the number of qualified science and non-science teachers supplied to the State's secondary schools from higher institutions in neighbouring States.

Table $7 \quad$ Number of qualified science and non-science teachers supplied to secondary schools in Ondo State, Nigeria from sources outside the State

\begin{tabular}{|c|c|c|c|c|c|c|c|c|}
\hline Years & $\mathrm{N}$ & $\begin{array}{l}\text { Total } \\
\text { number } \\
\text { of } \\
\text { qualified } \\
\text { teachers } \\
\text { supplied }\end{array}$ & $\begin{array}{l}\text { Number } \\
\text { of } \\
\text { qualified } \\
\text { science } \\
\text { teachers } \\
\text { supplied }\end{array}$ & $\begin{array}{l}\text { Number of } \\
\text { qualified } \\
\text { science } \\
\text { teachers } \\
\text { supplied from } \\
\text { higher } \\
\text { institutions in } \\
\text { neighbouring } \\
\text { States }\end{array}$ & $\%$ & $\begin{array}{l}\text { Number } \\
\text { of } \\
\text { qualified } \\
\text { non- } \\
\text { science } \\
\text { teachers } \\
\text { supplied }\end{array}$ & $\begin{array}{l}\text { Number of } \\
\text { qualified non- } \\
\text { science teachers } \\
\text { supplied from } \\
\text { higher } \\
\text { institution in } \\
\text { neighbouring } \\
\text { States }\end{array}$ & $\%$ \\
\hline 2002 & 16 & 9856 & 3152 & 1732 & 54.9 & 6704 & 3189 & 47.8 \\
\hline 2003 & 16 & 10,442 & 3550 & 2027 & 57.1 & 6892 & 3218 & 46.7 \\
\hline 2004 & 16 & 11,893 & 3806 & 2070 & 54.4 & 8087 & 3851 & 47.6 \\
\hline 2005 & 16 & 12,745 & 4210 & 2169 & 51.5 & 8535 & 3955 & 46.3 \\
\hline 2006 & 16 & 14,651 & 5134 & 2660 & 51.8 & 9517 & 4496 & 47.2 \\
\hline
\end{tabular}

In Table 7, greater numbers of qualified science teachers were supplied from higher institutions in neighbouring States than those supplied within the State in each of the years of study. In 2002, out of the 3152 qualified science teachers supplied, 1732 (54.\%) were supplied from higher institutions in neighbouring States whereas, out of the 6704 qualified non-science teachers supplied, 3189 (47.8\%) were supplied form higher institutions in neighbouring States. Likewise, in 2006, out of the 5134 qualified science teachers supplied, 2660 (51.8\%) were supplied from higher institutions in neighbouring States whereas out of the 9517 qualified non-science teachers supplied, 4496 (47.2\%) were supplied from higher institutions in neighbouring States. Figure 4 shows the graphical representation of the supply of qualified science and non-science. 
The Supply of Science Teachers to Secondary Schools in Ondo State, Nigeria: A Critical Analysis Adeyemi, T. O.

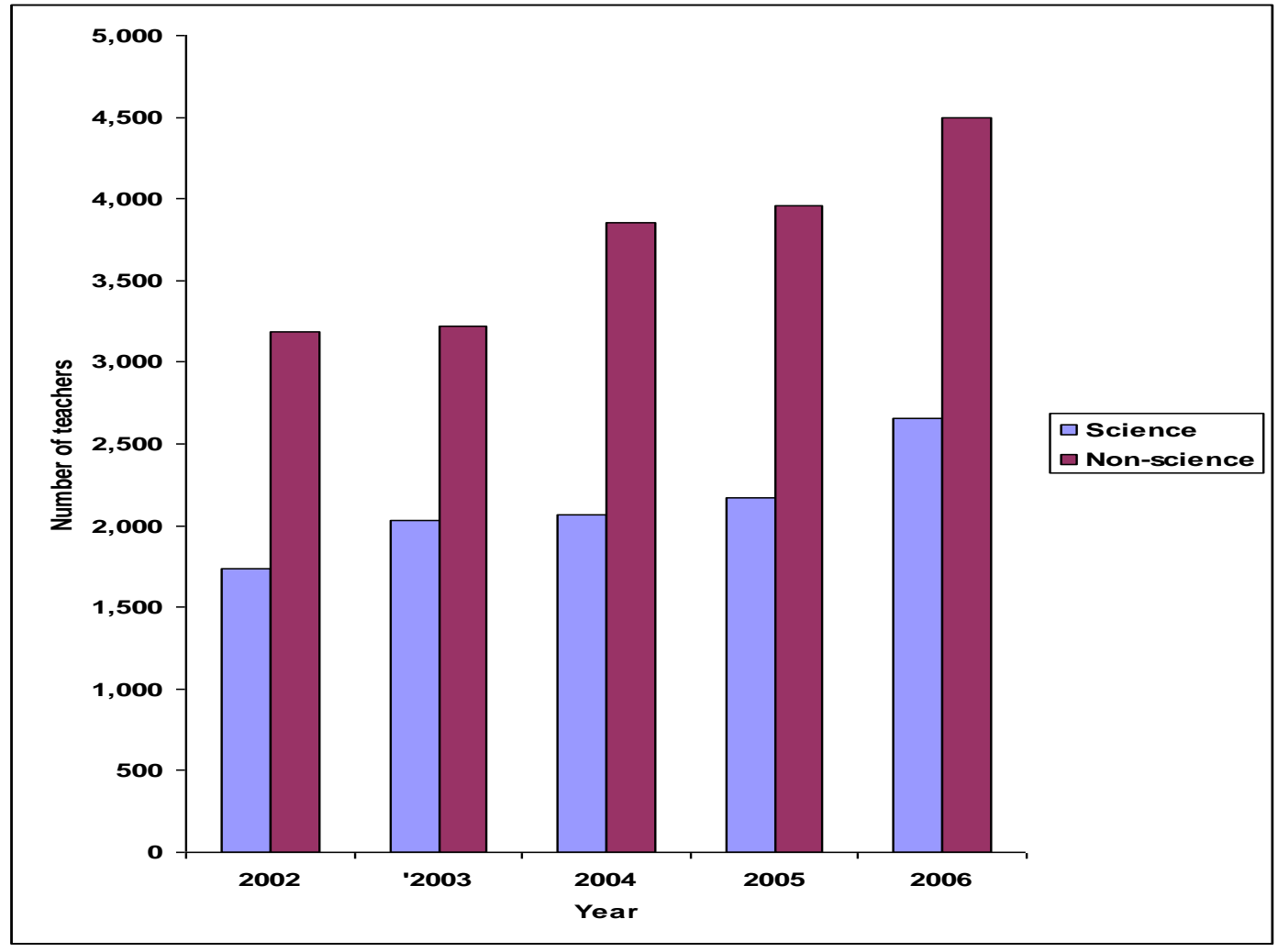

Figure 4 Graph on the supply of qualified science and non-science teachers from neighbouring higher Institutions outside the State

In Figure 4, the graph shows considerable difference in the number of qualified science and nonscience teachers supplied from the higher institutions to the schools. This shortfall in the number of science teachers confirmed earlier findings that greater numbers of science teachers were supplied from higher institutions outside the State than those supplied within the State.

\section{Question $5 \quad$ Does the supply of qualified science teachers match the demand for them in secondary schools in Ondo State, Nigeria?}

In answering this question, data on the numbers of qualified science teachers supplied from the higher institutions within and outside the State were collected from the Heads of Departments of the sampled higher institutions through the use of the inventory. The numbers of qualified science teachers demanded in the schools were also collected from the principals of the schools using the inventory. The demand was based on the Government's approved teacher quota of $1 \frac{1}{2}$ teachers per class of 30 students (Ondo State, Ministry of Education, 1994). Table 8 shows the students' enrolment, enrolment growth rates and the number of qualified teachers demanded during the period. The data collected were collated and analyzed using frequency counts and percentages. 
Table 8

Number of qualified science teachers demanded and the numbers supplied to secondary schools in Ondo State, Nigeria

\begin{tabular}{|c|c|c|c|c|c|c|c|}
\hline Years & $\begin{array}{l}\text { Total } \\
\text { number of } \\
\text { science } \\
\text { students } \\
\text { enrolled }\end{array}$ & $\begin{array}{l}\text { Number of } \\
\text { classes at } \\
\text { the rate of } \\
\text { the student- } \\
\text { teacher ratio } \\
\text { of } 1: 18 \\
\text { derived in } \\
\text { Table } 4 \text {. }\end{array}$ & $\begin{array}{l}\text { Number of } \\
\text { teachers } \\
\text { demanded at } \\
\text { the rate of } \\
1 \frac{1}{2} \text { teachers per } \\
\text { class }\end{array}$ & $\begin{array}{l}\text { Total number of } \\
\text { teachers supplied } \\
\text { by higher } \\
\text { institutions } \\
\text { within the State } \\
\text { and from } \\
\text { neighbouring } \\
\text { States }\end{array}$ & Shortfall & $\begin{array}{l}\% \\
\text { Shortfall }\end{array}$ & $\begin{array}{l}\text { Growth } \\
\text { Rate in } \\
\text { Teacher } \\
\text { supply }\end{array}$ \\
\hline 2002 & 55,601 & 3089 & 4634 & 3152 & 1482 & 31.9 & - \\
\hline 2003 & 55,618 & 3090 & 4635 & 3550 & 1085 & 23.4 & 12.6 \\
\hline 2004 & 61,716 & 3429 & 5144 & 3806 & 1338 & 26.0 & 7.2 \\
\hline 2005 & 63,885 & 3549 & 5324 & 4210 & 1114 & 20.9 & 10.6 \\
\hline 2006 & 65,242 & 3625 & 5438 & 5134 & 304 & 5.6 & 21.9 \\
\hline \multicolumn{8}{|c|}{ Average Growth Rate $=13.1$} \\
\hline
\end{tabular}

In Table 8, it was found that the supply of qualified science teachers did not match the demand for between in each of the years of study. The demand of qualified science teachers was found to be higher than the supply during the period. In year 2002, for instance, 4634 qualified science teachers were expected to be in secondary schools in the State. But only 3152 qualified science teachers were supplied from the higher institutions within and outside the State leaving a shortfall of 1482 science teachers (31.9\%). The shortfall was 23.4\% in 2003, 26.0\% in 2004 and $20.9 \%$ in 2005. It was only in year 2006 that the shortfall was low. Out of the 5438 qualified science teachers required in all the schools in 2006, 5134 qualified science teachers were supplied from the higher institutions leaving a shortfall of only 304 (5.6\%).. Figure 5 shows the graphical representation of the supply and demand for teachers in the schools.

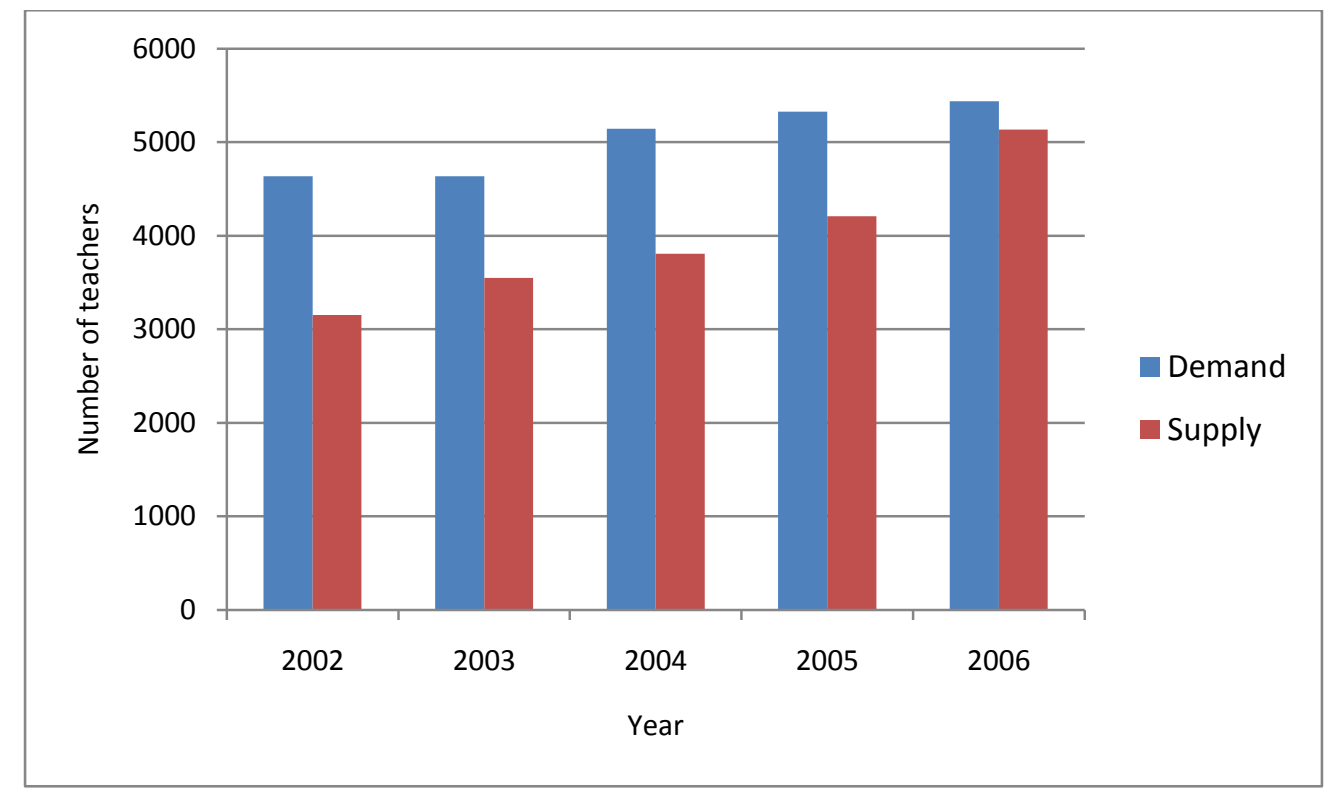

Figure 5 Supply of qualified science teachers and the demand for them in secondary schools in Ondo State, Nigeria 
In Figure 5, the graph shows a considerable mismatch between the supply and demand for teachers in the schools. Although there was an improvement in the supply of qualified science teachers to the schools, the supply has not met up with the demand for them in the schools.

Question $6 \quad$ What is the projection of supply of and demand for science teachers to secondary schools in the State for the period 2007 to 2016 ?

In response to this question, data on the number of students offering science subjects in the schools were collected from the principals of the schools through the inventory. Data on the number of teachers teaching science subjects in the schools were also collected. Data on the enrolment growth rate of science students in the schools were derived from the data in table 2.1 of the study. Data on the student teacher ratio in science subjects in the schools were derived from the data collected in Table 4. Data on the enrolment growth rate in the supply of science teachers to the schools were derived from the data on Table 8 of the study.

In projecting the number of science teachers' required in the schools between 2007 and 2016, the annual enrolment growth rate of $4.2 \%$ found in this study was used. The projection of enrolment was made using the following formula (Adesina, 1982):

$$
\begin{aligned}
\boldsymbol{P E}=\left(\mathbf{E}_{\mathbf{t}-\mathbf{1}}\right) & \times(\mathbf{A E G R})+\mathbf{E}_{\mathbf{t}-\mathbf{1}} \\
\text { Where: } & \text { PE IS projection of enrolment; } \\
& \mathrm{E}_{\mathrm{t}-1}=\text { Enrolment in year t-1 (i.e. previous year) while } \\
& \mathrm{AEGR}=\text { Average Enrolment Growth Rate. }
\end{aligned}
$$

The projection of science teachers' demand for the period was made using the teacher-student ratio of 1:19 found in this study. An attrition rate of 10 per cent for all teachers was assumed (Federal Republic of Nigeria, 1978). In computing the projection, the following formula was applied (Adesina; 1982).

$$
\begin{aligned}
& \mathrm{P}=\frac{\mathrm{En}}{\mathrm{Ts}} \\
& \text { Where: } \mathrm{P}=\text { Projection; En = Total Enrolment; } \mathrm{Ts}=\text { Teacher-student ratio. }
\end{aligned}
$$

Thus, on the basis of the enrolment growth rate of $4.2 \%$ and the $1: 18$ teacher-student ratio in science subjects found in this study, the projection of students' enrolment in science subjects in the schools and science teachers' demand from 2007 to 2016 is presented in Table 9. As indicated in the table, it was projected that 98,446 science students would be enrolled in secondary schools in the State by the year 2016. It was also projected that 5469 science teachers would be required in secondary schools in the State by year 2016. As such, the State government would require additional 1799 qualified science teachers by the year 2016 .

In projecting the supply of qualified science teachers to secondary schools in the State, data on the number of qualified teachers produced in the higher institutions within the State and in neighbouring States for secondary schools were collected from the Heads of various Departments of the Faculty of Education in the sampled higher institutions using the inventory. The data were analyzed using frequency counts and percentages. 
Table 9 Projected number of science students' and the demand for science teachers' in secondary schools in Ondo State, Nigeria (2007 to 2016)

\begin{tabular}{lcc}
\hline Years & $\begin{array}{c}\text { Base year 2006 enrolment of science } \\
\text { students }=65,242 \\
\text { Projected Enrolment at 4.2\% annual } \\
\text { growth rate }\end{array}$ & $\begin{array}{c}\text { Base year 2006 stock of science } \\
\text { teachers }=3670 \\
\text { Projected number of teachers required } \\
\text { using 1: 18 teacher-student ratio }\end{array}$ \\
\hline 2007 & 67,982 & 3777 \\
2008 & 70,837 & 3935 \\
2009 & 73,812 & 4101 \\
2010 & 76,912 & 4273 \\
2011 & 80,142 & 4452 \\
2012 & 83,508 & 4639 \\
2013 & 87,015 & 4834 \\
2014 & 90,670 & 5037 \\
2015 & 94,478 & 5249 \\
2016 & 98,446 & 5469 \\
\hline
\end{tabular}

Using the base year 2006 number of science teachers, 5134 supplied from higher institutions to secondary schools in the State and the $13.1 \%$ average annual growth rate in science teacher supply found in this study, the projection of science teacher supply from the higher institutions for secondary schools in the state from years 2007 to 2016 were made. The findings are shown in Table 10.

Table 10 Projected number of science teachers to be supplied from higher institutions for secondary schools min Ondo State, Nigeria (2007 to 2016)

\begin{tabular}{lc}
\hline Years & $\begin{array}{c}\text { Base year 2006 Teacher Supply }=5134 \\
\text { Average Annual Growth Rate }=13.1\end{array}$ \\
\hline 2007 & 5807 \\
2008 & 6568 \\
2009 & 7428 \\
2010 & 8401 \\
2011 & 9502 \\
2012 & 10,747 \\
2013 & 12,155 \\
2014 & 13,747 \\
2015 & 15,548 \\
2016 & 17,585 \\
\hline
\end{tabular}

As indicated in Table 10, the projection of supply of qualified science teachers from the higher institutions to secondary schools in Ondo state, Nigeria showed an upward trend. The projections shows that 17,585 qualified science teachers would be supplied by the higher institutions to secondary schools in the State by the year 2016. 
The Supply of Science Teachers to Secondary Schools in Ondo State, Nigeria: A Critical Analysis Adeyemi, T. 0.

\section{Discussions}

In the forgoing analysis, the issue of teacher supply in science subjects in secondary schools in Ondo State, Nigeria was examined. The findings show that science teachers were in few numbers in secondary schools in Ondo State, Nigeria. They were in less proportion compared to the number of non-science teachers in all schools in the State. On the average, they constituted only $33 \%$ of the total number of teachers in the schools in the State while non-science teachers constituted the remaining 67\%. This finding was a negation to the provision of the National Policy on Education which recommended a ratio of 40:60 science to non-science teachers in all secondary schools in the country (Federal Government of Nigeria, 2004). The finding indicating that male science teachers were in greater numbers than female science teachers tend to agree with the findings of earlier researchers (Enyong, 1986; Laurie, 1999).

The findings of this study reveal that the enrolment growth rate was $4.2 \%$ while the teacherstudent ratio among students offering science subjects and science teachers was 1:18. This appears to be a small ratio but it is a reflection of the fact that the number of students offering science subjects in the schools is always very small compared to the total number of students in the schools as evident in the findings in table 2.2. The finding was in consonance with those of previous researchers (Mallam, 1992; Adeyemi, 1998)

The finding indicating that the number of science teachers supplied from higher institutions in neighbouring States was greater than the number supplied from higher institutions within the State suggests that the bulk of the science teachers supplied to secondary schools in the State were supplied from higher institutions in neighbouring States. It also shows that the higher institutions in the State have not been able to supply the required number of science teachers to secondary schools in the State. It suggests that the higher institutions in the State had not been supplying sufficient numbers of qualified sconce teachers to all secondary schools in the State. The finding was consistent with those in earlier studies (Darling-Hammond, \& Dilworth, 1997; Snyder, 1999; Aghenta, 2001; MCEETYA, 2003). The finding indicating that greater numbers of non-science teachers were supplied from higher institutions within the State than qualified science teachers was also a negation to the provision of the National Policy on Education (Federal Government of Nigeria, 2004) which emphasizes the orientation of the country towards science and technology. This finding agreed with earlier findings (Nwadiani, 1996; Yasin, 1998).

The findings of the study indicating that the supply for qualified science teachers was less than the demand for them in each of the years of study is a reflection of the fact that the supply of qualified science teachers did not match the demand for them in the schools. This finding was consistent with the findings made in earlier studies (Jack, 1983; Yasin, 1998; Olugbile, 2007). The projection of 98,446 science students and 5469 science teachers in secondary schools in the State by the year 2016 as well as the findings that 17,585 qualified science teachers would be supplied by the higher institutions to secondary schools in the State by the year 2016. These findings were consistent with the findings made in previous studies (Gerald \& Hussar, 1998; Snyder, 1999; Akhaine, 2001; Onoja, 2005; Obaji, 2006). The findings suggest that adequate planning needs to be done to source for the necessary finance needed in the supply of qualified science teachers to schools. 


\section{Conclusion}

Based on findings of this study, it was concluded that there was a short supply of qualified science teachers to secondary schools in Ondo State, Nigeria. Evidences from the study have also led the researcher to conclude that emphasis in the State had been the supply of more nonscience teachers to secondary schools at the expense of qualified science teachers. in the same vein, it was concluded that higher institutions within the State had not been supplying sufficient qualifies science teachers to secondary schools in the State.

\section{Implications for Planning}

The findings of he study indicating that science teachers were in few numbers in secondary schools in Ondo State, Nigeria implies that adequate planning has not been put in place in the supply of sufficient qualified science teachers in the schools.. The fact that non-science teachers formed the bulk of teachers in secondary schools in the States shows that emphasis in the state had been on the production of non-science teachers. The situation is inimical to the technological development of the State and the country at large. The high enrolment growth rate of $4.2 \%$ found in this study also implies that urgent steps should be taken by the State government to increase the training and supply of science teachers to the schools.

The fact that the number of science teachers supplied from higher institutions outside the State was greater than the number supplied from higher institutions within the State implies that the higher institutions in the State had perhaps not emphasized an increase an the supply of science teachers in their institutions. Likewise, the fact that the supply of science teachers did not match the demand for them in secondary schools in the State might perhaps lead many students to change to non-science subjects The implication of this mismatch is that many prospective science students would end up offering non-science courses in higher institutions thereby leading to the over-production of non-science graduates at the expense of science graduates.

\section{Recommendations}

Considering the findings of this study, it was recommended that more efforts should be made by the State government to increase the supply of qualified science teachers to secondary schools in the State. Higher institutions in the state should be encouraged to increase the supply of more qualified science teachers in their institutions. Adequate planning strategies should be employed by the State government to source for the necessary funds needed in increasing the supply of qualified science teachers from higher institutions to secondary schools in the State.

\section{References}

Adesina, S. (1981) "What is Educational Planning?" Introduction to Educational Planning, S. Adesina (ed), Ile-Ife: University of Ife Press Limited, 45.

Adesina, S. (1982) Demand for Primary and Secondary Level Teachers in Ogun State, Ilorin: Faculty of Education. University of Ilorin,.9-10; 52 - 67.

Adesua, A. (1981) "Educational Finance in Nigeria" Introduction to Educational Planning (ed) S. Adesina: Ile-Ife: University of Ife Press Ltd Nigeria, pp. 115-129. 
The Supply of Science Teachers to Secondary Schools in Ondo State, Nigeria: A Critical Analysis

Adeyemi, T. O.

Adeyemi, T. O. (1998) School and teacher variables associated with the performance of students in the senior secondary certificate examinations in Ondo State Nigeria Unpublished $\mathrm{PhD}$ Thesis, University of Hull, England, United Kingdom; 2-25.

Aghenta, J.A (2001) Educational planning. A turning point in education and development in Nigeria, Inaugural Lecture Series 58 University of Benin, Benin-City, Nigeria.

Akangbou, S. D (1985) The economics of educational planning in Nigeria New Delhi: Vikas Publishing House P.V.T Ltd, 76-117.

Akhaine, S. (2001). Produce 30,000 teachers yearly, government mandates NTI. The Guardian, October 25, 38.

Ashby Report (1961) Investment in Education: Report of the Commission on Post-graduate and Higher Education in Nigeria, Lagos: Federal Ministry of Education.

Babbie, Earl R (1973) Survey Research Methods Belmont, California: Wadsworth Publishing Company Incorporated, 57-58, 317-324.

Bradley, A. (1999). States' uneven teacher supply complicates staffing of schools. Education Week, 18.

Darling-Hammond, L., \& Dilworth, M. E. (1997). Recruiting, preparing, and retaining persons of color in the teaching profession. Washington, DC: Office of Educational Research and Improvement (OERI).

Enyong, S.C.T. (1986) "Boarding secondary education in the Eastern States of Nigeria: Influences, Characteristics and Problems" Unpublished PhD Thesis, University of Hull UK, 299- 396.

Federal Government of Nigeria (2004) National policy on education, Lagos, Federal Ministry of Education, 7--45.

Federal Republic of Nigeria (1978) Implementation Committee for the National Policy on Education, Part One, Blue print. 1978-79, Lagos: Federal Ministry of Education,.49-84.

Gay, L. R (1996) Educational research: competencies for analysis and application; Upper Saddle River, New Jersey: Merrill, Prentice-Hall Inc, 249-305.

Gerald, D. E., \& Hussar, W. J. (1998). Projections of education statistics to 2008. Washington, DC: U.S. Department of Education, Office of Education Research and Improvement.

Ige, J. A. (2001) Teacher data in secondary schools in Ekiti State Speech delivered by the Permanent Secretary at the Senior Staff seminar, Ministry of Education, Ado-Ekiti 1-9

Jack, R.E (1983) "Problems of teacher supply in Rivers State Nigeria: A Study of Quantitative and Qualitative Shortages." Unpublished M.A Education Dissertation, University of Hull UK. 61.

Laurie M. D. (1999) Supply and Demand of Educational Personnel for Wisconsin Public Schools 1999 Supply and demand study http://www.dpi.state.wi.us/contact.html

Mallam, Winifred A. (1993) 'Impact of school-type and sex of the teacher on female students' attitudes toward Mathematics in Nigerian secondary schools" Educational Studies in Mathematics 24 (2) 227-228. 
MCEETYA (2003). Demand and Supply of Primary and Secondary School Teachers in Australia MCEETYA Secretariat http:www.mceetya.edu.au/mceetya/default.asp?id=11572

Moore, J. L. (1994) Research Methods and Data Analysis 1 Hull: Institute of Education, University of Hull UK. October, 9-11, 27-126.

Nwadiani, M. (1996), An Analysis of the Demand for and supply of Science Places in Nigeria Universities (1980-1989) Journal of Education and Society 2 (2), May, 47-57.

Nwankwo, J.I. (1981) Educational Planning, Theory and Methods (Nigeria), Lahore: Izharsons,.

Obaji, C (2006) Nigeria needs additional 200, 000 teachers Lagos: The Punch, $17(19,588)$ Friday, April 21; 8

Olugbile, S. (2007) Unqualified teachers in schools worry educationists Lagos; The Punch, 17 $(19,881)$ Friday, June 6, 30.

Ondo State Government (2000) Approval Budget Estimates 2000 Akure: Ministry of Finance and Economic development and Budget, 1-10.

Ondo State Government (2001) Approval Budget Estimates 2001 Akure: Ministry of Finance Economic development and Budget, 2.14...

Ondo State Ministry of Education (1985). Educational statistics Akure: Planning, Research and Statistics Department; 2-10..

Ondo State Ministry of Education, 2006) Secondary schools statistics, Akure: Planning, Research and Statistics Department; 1-5.

Onifade, A (2003) 'The Funding Problem', Vanguard education \& manpower 19 (5167) Thursday, January 16, 27- 29.

Onoja, U (2005) Kogi needs 2,515 teachers Ibadan: Nigerian Tribune No 13,769, Thursday $17^{\text {th }}$ November 43.

Sheehan, J. (1973) "Teacher Supply and Demand," Economics of Education, London: Allen \& Unwin, 106.

Snyder, T. (1999). Digest of education statistics, 1998. Washington, DC: National Center for Education Statistics, U.S. Department of Education.

Yasin, S. (1998). Teacher shortages across the nation: Implications for SCDEs.Briefs, 19 (12), 1.

Yasin, S. (1999) The supply and demand of elementary and secondary school teachers in the United States. ERIC Digest ED436529 http://www.Vmsatellite.com/?aid=51733; http://www.satellitetv.dd/; http://www.mceetya.edu,au/mceetya/default.asp?id=11940 